\title{
Double-Effect Reasoning in Paradise Lost: An Investigation into Milton's God's WiLL in Humankind's FALL
}

\begin{abstract}
Double-Effect Reasoning (DER) implies the coexistence of good and evil in certain affairs; for a good outcome to appear, the possible evil side effects in its company or deviating from it are foreseen-but-not-intended. In Paradise Lost, God's creation serves His eternal plan, which is in essence good. The evil that follows, through Satan's rebellion, Adam and Eve's disobedience, ecological deterioration, and the Son of God's sacrifice, also happen under God's plan. These evil happenings, as paradoxes within good ends, follow the ethical principle of DER. Hence Milton's paradoxes in justifying God's ways in creation and His prelapsarian plan for the perfection of humankind through the Fall. The ambiguities of God's plan, in bringing good out of evil, can thus be explained through DER as an inevitable theological issue, which tries to explain the archetypal symbiosis between contradictions.
\end{abstract}

Keywords

Double-Effect Reasoning; good and evil; justice; Paradise Lost

\section{Introduction}

Justifying God's ways to humankind is not fully understandable as there is always the paradox of the companionship of good and evil in God's affairs. If God is good, why has He let evil advance in the universe? If the world was created by a good and just God, why are there few signs of goodness and justice in the world? And if He knows everything even before it happens, why has He punished humankind for the Fall, which owed its roots to Satan's rebellion, itself Godly 
known and open to be prevented from happening? These are certainly answerable according to God's Providence and His Will in creation. However, within the human sphere such Godly knowledge is not available. Milton has highlighted this issue when he says in Christian Doctrine that "When we speak of knowing God, it must be understood with reference to the imperfect comprehension of man. For to know God as He really is, far transcends the power of man's thought, much more of his perception" (1957: 905). It is also reflected in Paradise Lost, as Raphael reminds Adam in Book VII that human mind is only able to make rules and judgments "within bounds": "to recount Almightie works / What words or tongue of Seraph can suffice, / Or heart of man suffice to comprehend?" (112-114). ${ }^{1}$ Comprehending God's plan is thus limited to the holy books in the religious sense and to human wisdom out of the religious context.

Among the numerous theological principles and ethical theories stand DoubleEffect Reasoning and its paradoxical nature of juxtaposing good and evil side by side, only to draw good out of evil or to make evil an inevitable company of goodness, combining them into a symbiotic relationship. As such, a part of God's plan may be comprehended, and it can be a key in understanding such religious concerns as those of Milton in Paradise Lost to "justify the ways of God to men" (I: 26).

\section{Theoretical foundation: double-effect reasoning}

The Principle of Double Effect (PDE), the Rule of Double Effect (RDE), the Doctrine of Double Effect (DDE), or more common, Double-Effect Reasoning (DER) (Cavanaugh 2006: $\mathrm{xx}$ ), is an ethical principle in justifying the permissibility of an action which causes serious harms, such as the death of a human being as a side effect of achieving a good end. In other words, sometimes it is legible to cause evil as a predictable side effect or "double effect" in bringing about goodness, although it is not permitted to cause evil deliberately as a tool to bring about goodness (McIntyre 2014). In the Roman Catholic moral theory, specifically the Thomist doctrine, DER has been developed "especially to deal with moral dilemmas, in which conformity with an absolute moral rule seems to be morally unacceptable (Mautner 2005: 168). Thomas Aquinas, commenting on St. Augustine's theology, is credited with introducing this principle in discussing whether homicidal self-defense is permissible in the Summa theologica (II-II q.64 a.7)2 (McIntyre 2014; Cavanaugh 2006: 1). Aquinas discusses the morality of the case in which an individual kills an assailant in self-defense. He quotes Augustine, who in On the Free Choice of the Will asks, "How indeed are they free of sin in the eyes of divine providence? [... those] stained with human blood for the sake of things that should be held of little worth" (2010: I.5.12.39). Aquinas interprets things of little worth, like the intentional killing of an assailant (1981: II-II q.64 a.7). According to Cavanaugh, Aquinas here holds that Augustine considers "one's own life among the slight goods that men ought to forfeit rather than kill 
another." As such, Augustine seems to hold that an individual "may not take an assailant's life in self-defense" if it is intentional (Cavanaugh 2006: 3). Thus, in defending the unintentional sort of homicidal self-defense, Aquinas believes that

Nothing prevents one act from having two effects, of which only one is intended, the other being praeter intentionem [outside the moral intention]. Now moral acts receive their character according to that which is intended, not, however, from that which is praeter intentionem, since this is accidental. (1981: II-II q.43 a.3)

Aquinas thus justifies the foreseen-but-not-intended murder of an assailant, "since what is intended is the conservation of one's own life" (II-II q.43 a.3). Although Aquinas applies such justification to "difficult moral cases" (Cavanaugh 2006: 1), his argument extends into elaborations on the problem of evil in the universe too, as will be mentioned later. However, it is through later elaborations that DER concentrates on the overall distinction between causing a morally serious harm as a side effect of fulfilling a good aim and causing a serious harm as the only means of fulfilling a good aim (McIntyre 2014). Accordingly, DER is used in analyzing the "exceptional cases in which we cannot realize a good end without also causing a bad effect" (Cavanaugh 2006: 46). As such, the conditions which legitimize double-effect reasoning still draw from Aquinas's views.

According to Cavanaugh, drawing from Aquinas (1981: I-II q.18 a.1), to ethically assess an act, attention should be paid to three issues: "what the agent does (the deed or the object), the circumstances in which the agent does it (when, where, how, to whom, and with what), and the end or reason for which the agent acts" (Cavanaugh 2006: 7). According to Aquinas's argument regarding the role of intention in analyzing an act, it becomes clear what he has in mind in asserting that "moral acts receive their character according to what is intended, not according to what is praeter intentionem, since this is accidental." Unlike an intention which is essential, according to Cavanaugh, what is praeter intentionem is not essential "in establishing the agent's action as good or as bad" (Cavanaugh 2006: 9). What is praeter intentionem is not intended at all; the "willing of an end" causes one to think about the means, which upon discovery is chosen and intended "in a plan of action". As such, one does not will the means even if it causes evil (137). Therefore, there is a difference between an action causing evil "as an end" and one causing evil "as a means" (138). Aquinas's three aspects of an action causing goodness without intentional evil side effects are thus remodeled as "four necessary conditions":

1. The action should be morally good;

2. The agent should intend the good effect and not the evil one;

3 . The good effect should not be generated by the evil one;

4. There should be a proportionately grave reason for causing evil (Cavanaugh 2006: 26); or "the goodness of the intended good effect" must be satisfactory "to outweigh the foreseen transgression" (Mautner 2005: 169). 
As such, DER considers the detrimental effects remorsefully intended as part of the agent's plans, plans which are impermissible in relation to the detrimental effects remorsefully predicted as side effects (McIntyre 2014). Accordingly, the first condition "echoes the impermissibility of intrinsically wrong acts" (Cavanaugh 2006: 27). In the second condition, the agent "does not intend the evil, neither as his means nor as his end" (28). The third condition is rather "redundant", since "when one understands it as asserting that the agent may not intend the evil effect as a means or as an end," it echoes the second condition (29-30). And the fourth condition compares "one's reasons for doing the good" to "one's reasons for avoiding the evil." Action here needs the "proportionate gravity" of one's rationality for causing the good (31). Therefore, excluding the redundant third condition, the conditions turn into three general ones:

1. The action which is considered independently of its evil effect should not in itself be wrong;

2. The agent should intend the good and not the evil "either as an end or as a means";

3. The agent has "proportionately grave reasons for acting, addressing his relevant obligations, comparing the consequences, and, considering the necessity of the evil, exercising due care to eliminate or mitigate it." (36)

In general, these formulations require that good ends overshadow their possible harmful side effects. As such, DER is covertly present in cases where the permissibility of the deliberate death of or harm to a creature, including humankind, is concerned. Killing for pleasure is pure evil and an ultimately pure crime. But the point becomes challenging when willing deliberate deaths serves good ends, as in the collateral damage inherent in a tactical bombing - of course, when we are concerned with evil enemies, abortion in problematic pregnancies, euthanasia, self-defense, for instance. In each case, the evil side effects which follow or accompany such actions are considered permissible as far as they are not intended but means to a good end. The collateral damage in a tactical bombing has the evil side effect of endangering non-combatants' lives; saving the mother in problematic pregnancies endangers the life of the fetus, even its death, so that the mother survives; euthanasia relieves a suffering human being from pain; and homicidal self-defense, in essence not intended to kill the assailant, helps the attacked person survive while endangers the assailant's life. In all these cases, the foreseen-and-not-intended death of others is likely to occur, since it serves higher and better purposes including security, survival, or relief from pain. These cases lie in contrast to intentional cases of murder or evil as ends in themselves, such as "terror bombing" and "sadistic bombing" which consist of "willing terror and non-combatant deaths as means to the end of victory (intending them as means)" (Cavanaugh 2006: 139). 


\section{DER and the problem of evil}

According to the principle of DER, the goodness and badness of an action have "moral import[s]" and enter into "act-evaluation" only when an agent "knowingly and willingly" causes or allows the action "as an end, as a means, or as a concomitant". Accordingly, an action is "right or wrong" or "better or worse" in terms of such "volitional states" (Cavanaugh 2006: 143). As Nagel says, "the essence of evil is that it should repel us"; therefore, "if something is evil, our actions should be guided [...] toward its elimination rather than towards its maintenance. That is what evil means" (1980: 132). Nagel's viewpoint partially echoes Aquinas's articulation of the first ethical principle, to voluntarily "do good and avoid evil" (1981: I-II q.94 a.2). The question is "How ought we to act when the doing of good involves a failure to avoid evil and the avoidance of evil involves a failure to do good?" (Cavanaugh 2006: 144). It is to argue that when we cannot "avoid evil without sacrificing a comparable or greater good," we may intend good and not evil. Intending evil makes it an "ultimate goal" (145); "when one intends evil, one relates to evil as good," thus inverting proper choosing. Accordingly, while intending to avoid evil is permissible, intending evil while doing something good is impermissible. However, when good and evil inseparably tie together, "neither doing good nor avoiding evil alone suffices for an ethical act" (146). As an example, the first instance of intending evil - "all Good to me is lost; / evil, be thou my good", as Milton has Satan express his intention ( $P L$, IV. 109-110) - corrupts the "basic normative relationship" that goodness has with evil (Cavanaugh 2006: 145); Milton's Satan intends evil as an end in itself and does not try not to intend evil.

The first case of evil was intended and committed by Satan, which in turn caused the Fall. And God knew that Satan would intend and do evil. So the question is why does God permit evil if He is ultimate goodness? God's goodness shall deem that whatever happens in the universe follows His Will, which is in essence good. Therefore, our logic holds that evil shall serve that goodness, if evil is not to exist in itself. As Augustine says in his Confessions, "evil has no existence except as a privation of good, down to that level which is altogether without being" (2009: III. 7). ${ }^{3}$ Quoting Augustine's view in the Summa, Aquinas explains that

Whoever knows a thing perfectly, must know all that can be accidental to it. Now there are some good things to which corruption by evil may be accidental. Hence God would not know good things perfectly, unless He also knew evil things. Now a thing is knowable in the degree in which it is; hence since this is the essence of evil that it is the privation of good, by the fact that God knows good things, He knows evil things also; as by light is known darkness. (1981: I q.14 a.10)

But God's knowledge does not cause evil; it is "the cause of the good whereby evil is known." Knowing a thing merely by something else "belongs to imperfect 
knowledge, if that thing is of itself knowable." However, "evil is not of itself knowable," being in essence good perverted. Thus, "evil can neither be defined nor known except by good" (I q.14 a.10), and good merely derives from God. It is merely the good that can stand as "a cause", since "nothing can be a cause" without having "a being"; "every being, as such, is good." Therefore, Aquinas holds that "evil has no formal cause, rather is it a privation of form", reflecting Augustine. Likewise, evil has no "final cause"; it is "a privation of order to the proper end". That is because it is not merely the end which has "the nature of good", but also "the useful, which is ordered to the end." As such, evil has merely "an accidental cause"; and "thus is good the cause of evil" (I q.49 a.1). In general,

Never therefore would evil be sought after, not even accidentally, unless the good that accompanies the evil were more desired than the good of which the evil is the privation. Now God wills no good more than He wills His own goodness; yet He wills one good more than another. Hence He in no way wills the evil of sin, which is the privation of right order towards the divine good. (1981: I q.19 a.9)

Such an attempt to clarify God's reason for permitting evil is a "theodicy", which is to show that "God is just in permitting evil" (Plontingo 2002: 27). And in Milton's words, it is an attempt to "justifie the wayes of God to men" (PL, I. 16).

\section{DER and justifying the ways of Milton's God to humankind}

Monotheism, taking God as "both benevolent and omniscient" (Poole 2005: 14), is always concerned with an essential problem, as Boethius concretely puts it: "[if] there be a God, from whence proceed so many evils? And if there be no God, from whence commeth any good?" (Boethius 1609: 31; qtd. in Pool 2005: 14). It is the first question that "necessitates the device of the Fall" to explain the coexistence of "the God of love" and evil in the universe (Poole 2005: 14). Such an important event as the Fall must be meaningful; if the Fall is to end in humankind's ultimate damnation until the Apocalypse, then it is in a process of causing boundless evil. But, according to God's Providence, if His Grace or the Son of God's sacrifice is to redeem humankind, the Fall must be in essence or intention good. Thus, we can pose simpler questions: was God unable to choose a way other than banishment from Paradise and death to punish Adam and Eve so that they would begin to repent and ask for God's mercy afterwards? Was not God able to choose something other than the Fall as a means for human salvation? And, to use DER, has God intended something good by the Fall, which had evil as its foreseen-but-not-intended side effect?

In the theological sense, death is God's punishment for the original sin. The Biblical version holds that God warned Adam not to eat from the fruit of the Tree of Knowledge of good and evil, "for in the day that thou eatest thereof thou shalt 
surely die" (Gen. 2:17). Milton discusses the permissibility of this judgment regarding God's ways to humankind throughout Paradise Lost. Death thus befell humankind because of the evil that had penetrated Paradise through disobedience.

According to Danielson, the "theological problem of evil" is concerned with balancing three basic propositions common among all theodicies:

1. God is omnipotent and all powerful.

2. God is totally good.

3. Evil exists in the world.

The third proposition contradicts the first two ones, as it seems. Arguments over these conditions are likewise contrary. "Dualists" deprave God of His omnipotence; "voluntarists" describe "God's goodness merely as a function of God's will, or power" so that whatever God wills is good; "optimists" consider the evil in the universe not as pure evil but "as a necessary part of some universal good." Milton rejects all the contradictory attempts at reconciling these elements in favor of his specific theodicy in Paradise Lost to justify God's ways to humanity (Danielson 1999: 146). As Book X comes to an end, Milton has succeeded to explain what God did and why He did so, but his attempt at illuminating God's ways of justification remains immature, a problem that he compensates for in Books XI and XII. The questions would be what was the essence of the prelapsarian signs of evil in God's realm, and "can the single instance of disobedience by Eve and then Adam justify death, war, plague, famine - an endless list of evil" in the world? (Linn 2001: 73). In truly accomplishing his goal, Milton is then willing to highlight what the Fall did for the future of humankind, simultaneously discussing the notion that some higher goodness than immortality in Paradise and innocence were to follow the Fall.

By placing God in a "Yahwistic role" in Book III, as was the image of God in the Old Testament regarding His "Thou Shalt[s]" and "Thou Shalt Not[s]", Milton presents God "both as capable of good and evil" (Bryson 2002: 91). According to Lewalski, Milton in his Christian Doctrine argues that all ideas about the incomprehensibility of God are "necessarily metaphoric"; however, these ideas should "correspond to the way God has presented himself in the Scriptures." As such, Milton presents the God of Paradise Lost with "a range of emotions (fear, wrath, scorn, dismay, love)", just as the Jehovah of the Old Testament reveals such features (Lewalski 2007: xxiv). Therefore, in "justifying" the ways of such God to humankind, the theological doctrine of justification itself shall be illuminated.

The word "justify", as Milton used it, follows the theological principle of "the Protestant reformulation of the justification doctrine." This implies discussing the possible validity of explaining "the injustice of" an agent or an action. As old as the Holy Bible itself, justification bears the processes through which sinful humanity is "either made or declared righteous in the sight of God" (Bryson 2002: 92). However, this issue has affinities with Augustine and Aquinas, who consider 
justification as the process through which God made righteousness out of human fault. Protestantism deviated from this view of justification, in accordance with the "shift in humanity's being" in the Renaissance, and preferred to interpret it "as a change in humanity's status". Lutheran and Calvinist Protestantism interpreted justification as "God imputing righteousness to humankind" through faith in Christ's sacrifice. Being announced "righteous" before God suggested that one is not "ontologically changed" but "merely credited with something one does not actually have." As such, justification could be observed as a kind of spiritual gift given to the "essentially uncreditworthy humanity". This view of justification, however, presupposed a "legalistic dualism" (Bryson 2002: 92). Richard Baxter, Milton's contemporary, held that justification acquits us "from the charge of breaking the Law", and that justification implies "accusation" (1649: 135). Milton reversed this definition, as Bryson believes; when Milton announces that he will try to justify the ways of God to humankind, he is in fact announcing "his intent to accuse God in order to acquit God" (Bryson 2002: 92). Justifying God's ways implies accusing God of what he did to humankind, simultaneously as it is exonerating God from any cruelty toward humankind.

Justification here is directly linked to the concepts of the Original Sin and God's Grace, that is, how God is justified in letting the Fall happen. Since the Western origin of the concept of the Original Sin "lies squarely with Augustine of Hippo" (McFarland 2010: 61), his arguments regarding the Fall and their reflection in Milton's vision are important to highlight. Augustine's view of the Fall was nearly related to his ideas about "the inability of man to win grace for himself, and the damnation of the majority of mankind" (Poole 2005: 197). As McFarland holds, Augustine's emphasis on human depravity is not for the sake of depravity itself, as if Augustine is theologically a misanthropist, "but as a corollary of the good news of the gospel" (McFarland 2010: 33): that "it is by grace you have been saved, through faith - and this is not from yourselves, it is the gift of God" (Eph. $2: 8)$. The Original Sin is vital for Augustine, since it guarantees the point that all human beings "need saving" (McFarland 2010: 33). Augustine's "soteriological" worldview towards the Fall highlights the Son of God's unique position in the universe, who is to redeem humankind's sin (McFarland 2010: 32). Adam and his children are then unable to win salvation all on their own. If the Fall was to remain on its own, there would be no Son of God to prove his power in humankind's destiny, and the Fall would have remained a phenomenon in essence evil. Thus, God's ultimate Grace, manifested in the Son of God's sacrifice to purify humankind, turns the Fall into a side effect as it was a process and not a product. According to Lewis (1969), Milton's version of the Fall is "substantially" after St. Augustine's, based on some doctrines (67). In Augustine's view, God created all things without exception good, and because they are good, "No Nature (i.e. no positive reality) is bad and the word Bad denotes merely privation of good" (1957-72: XI. 21, 22). Milton's God thus says of Adam, "I made him just and right" and that "such I created all th' Etherial Powers" (PL, III. 98, 100). And Raphael says, "one Almightie is, from whom / All things proceed, and up to him return, / If not deprav'd from 
good, created all / Such to perfection" (V. 469-472). Then follows what we call evil, that is, goodness perverted, in Augustine's theology (1957-72: XIV. 2). Such perversion occurs when a conscious creature finds more interest in itself than in God (XIV. 11), and wishes to exist "on its own" (XIV. 13). This is when the sin of Pride is born, Satan being its first originator, that "proud angel who turned from God to himself, not wishing to be a subject, but to rejoice like a tyrant in having subjects of his own" (XIV. 11). As Lewis says, Milton's Satan "exactly conforms to Augustine's description" (1969: 66). Satan is primarily concerned with his own self-respect, revolting because he thinks "himself impaired", betraying his Creator $(P L, \mathrm{~V} .665)$. And finally, although God has created all the creatures good, $\mathrm{He}$ knows that some will voluntarily commit badness, of which He will make a good use (1957-72: XIV. 11). For, as God reveals His goodwill in creating goodness, $\mathrm{He}$ reveals His justice in exploiting evil intentions (XI. 17). Likewise in Milton, God sees Satan coming to pervert humankind - Satan "shall pervert", God observes ( $P L$, III. 92). God knows that Sin and Death "impute folly" to Him for allowing them so easily to enter the universe (X. 620-621), but they do not know that God "call'd and drew them thither, His hell-hounds to lick up the draff and filth" (X. 629-630). The same doctrine is enforced in Book I when Satan lifts his head from the burning lake by "high permission of all-ruling Heaven" (I. 212). As the angels point out, whoever tries to rebel against God produces the result opposite to his intention (VIII. 615), suggesting that God's intention is in essence good. At the end of the poem Adam is astonished at the power "that all this good of evil shall produce" (XII. 470). Thus, "those who will not be God's sons become His tools" (Lewis 1969: 68). As such, even if the Fall was merely to serve evil, God would have used it towards goodness.

On the other hand, following Arminianism, Milton believed in the practice of human free will towards salvation. As such, Milton essentially rejected "Calvinist determinism", prevailing in the early seventeenth-century orthodox Protestant theology and among Calvinist Puritans (Loewenstein 2004: 74). Milton acquits God from the responsibility of the Fall. Milton's God reemphasizes this point among angels and the Son of God after the Fall, that "no Decree of mine" was "Concurring to necessitate his [Adam's] Fall" or weaken "His free will" (PL, X. 44-46). Accordingly, God stresses “the poem's Arminian emphasis on man's free agency in his salvation" (Loewenstein 2004: 74):

So without least impulse or shadow of Fate,

Or aught by me immutably foreseen,

They trespass, Authors to themselves in all

Both what they judge and what they choose; for so

I form'd them free, and free they must remain,

Till they enthrall themselves. (PL, III. 120-125)

The point is that free will presupposes both right and wrong consequents. In Book III, God discusses that if obedience to Him was obligatory on the side of 
humankind, it would be worthless: "Not free, what proof could they have given sincere / Of true allegiance, constant Faith, or Love, / Where onely what they needs must do, appeard, / Not what they would? what praise could they receive?" (PL, III. 103-106). God receives no "pleasure" from "passive" obedience which merely serves necessity, will and reason remaining "useless and vain", freedom "despoild". Such passivity does not serve God (III. 107-111). Consequently, bestowing free will on humankind has the evil possibility of disobedience; since "true allegiance" to God is extremely greater than being "not free", God allows the evil side of free will to coexist with the good part. Had God prevented the Fall, He would have ruined humankind's free will:

I formd them free, and free they must remain,

Till they enthrall themselves; I else must change

Thir nature, and revoke the high Decree

Unchangeable, Eternal, which ordain'd

Thir freedom ... (PL, III. 124-128)

God's insistence on humankind's free will is important in revealing the justice of His ways. Therefore, despite acquiring the knowledge about the destruction that Sin and Death will bring to the world, "Adam is able to proclaim the goodness of God's ways as the meaning of the messianic promises becomes clear to him" (Lewalski 2007: xxv). The notion that human reason and will must be "tested and strengthened in their capacity to distinguish true good from apparent good" underlines Milton's Areopagitica as well (Lawrence et al. 1985: 282). There Milton develops "a theory of virtue that promotes contact with evil" (Poole 2005: 138):

Good and evil we know in the field of this world grow up together almost inseparably; and the knowledge of good is so involved and interwoven with the knowledge of evil, and in so many cunning resemblances hardly to be discerned, that those confused seeds which were imposed on Psyche as an incessant labor to cull out and sort asunder, were not more intermixed. It was from out of the rind of one apple tasted, that the knowledge of good and evil as two twins cleaving together leapt forth into the World. And perhaps this is that doom which Adam fell into of knowing good and evil, that is to say of knowing good by evil. (Milton 1957: 728)

Accordingly, virtue, having not faced evil, is not true virtue. Reflecting Augustine, that "God does not produce our salvation in us as if we were mindless rocks or beings in whose nature he did not create reason and will" (Augustine 1997b: 2.6), Milton thus says that the virtue "which is but a youngling in the contemplation of evil, and knows not the utmost that vice promises to her followers, and rejects it, is but a blank virtue, not a pure." In order to possess true virtue, one shall then know not only good but also evil. Virtue, just like obedience, derives from the freedom of choice. However, the act of choosing presupposes the fact that one 
shall have alternatives from which to choose, since "what wisdom can there be to choose, what contingence to forbear without the knowledge of evil?" Therefore, "a fugitive and cloistered virtue" is not praiseworthy (Milton 1957: 728). Milton thus emphasizes that all notions, even those reflecting error, end up with the acquisition of truth if the mind is righteously governed. "Liberty of thought and speech are thus essential in the formation of virtue" (Innes-Parker 2011: 598).

According to Poole, Milton's argument above is "a version of the felix culpa," since "felicity and culpability" are both considered as constituents of the Fall. But Milton's argument does not mean that these two elements are "in equilibrium". Adam here did not fall into a terrible state "in which Christ blazes on the horizon," but he fell from a "pre-ethical" state; Adam fell into "a state of ethical cognition" (Poole 2005: 138). Such state after the Fall suggests "implicit questions about the precise nature of the good before it, if Milton is so celebratory of goodwith-evil" (139). Milton's concern here dates back to one of the opening remarks in the Commonplace Book: "Why does God permit evil? So that reasoning and virtue might be able to correspond. For the good is made known, is made clear, and is exercised by evil" (363). ${ }^{3}$ As was mentioned earlier, anything self-directed and away from God and His Goodness is pure evil. However, if evil is to cause goodness, since it is not intended but is merely a means to an end or a foreseenand-not-intended side effect, it is permissible. As Augustine says,

We never read in the Holy Scriptures: There is no will except from God. And it is right that the scripture does not say that, because it is not true. Otherwise, if there were no will except from God, God would be - heaven forbid! - the author even of sins. For an evil will by itself is already a sin, even if the execution is lacking, that is, if the will lacks the power. But when an evil will receives the power to carry out its intention, it comes from the judgment of God with whom there is no injustice. (1997a: 54)

Regarding Adam's fall, for instance, Augustine believes that "in Adam's transgression the evil act was preceded by an evil will"; "the evil act could not have been arrived at if an evil will had not gone before" (1957-72: 14.13). This is the most essential point in applying the double-effect reasoning in discussing God's foreknowledge, human will, the Fall, and God's Grace. Though God knows that human freedom and will do bring evil, He lets evil happen because of His justice. And when evil happens, God uses it towards good ends to reveal His Grace.

However, DER has nothing to do with Satan's rebellion, Eve's temptation, and Adam's sin on separate grounds, since their evil action followed an evil will or intention. Satan revolts against God and His Son out of pride, a fact presupposing the existence of evil will or its knowledge in the universe even among angels, pointing to their free will. Milton here again echoes Augustinian theology in holding that deviating from goodness causes evil, especially when the committing agent has will over what he/she does. In Milton's theological doctrines, angels have will over their actions too. On their own and away from God, any 
willing subject commits evil for its own sake, challenging the ordained good. As such, the intended act is essentially evil. The fallen angels' sin derives from "the evil of a Satanic individualism" that turned in upon themselves and recognized no other being other than their own "will and force" (Colebrook 2008: 9). Milton's Satan, unlike humankind, "has not been deflected by false moral reasoning" or deceit; he has determined to "base values not on morality, norms or the order of the world" but on his own "unconquerable will" (3). His crime lies in "his choice of evil as good" (Steadman 1976: 266). Regarding Eve's temptation, she mistakes evil for good, although she commits the sin for the sake of a heavenly position. But since she has no knowledge of the evil she is doing, as she is being tempted by a knowledgeable agent possessing knowledge of evil, her action merely generates further evil. Her action is inherently evil from the Divine outlook, since her initial position in the universe is a Godly given one against which she rebels, tempted by jealousy. Augustine holds that God has not created humankind strong enough against temptation, since human beings can "will both good and evil" (1955: XVIII. 105). Likewise, Milton's God says, "I made him just and right, / Sufficient to have stood, though free to fall" (PL, III. 98-99). For Milton's God, Adam and Eve are "Authors to themselves", "they themselves decreed / Their own revolt, not I"; "They themselves ordain'd thir fall" $(3.122,116-117,128)$; they are their own jailors and "enthrall themselves" (3. 125). Eve also proves infidel to the promise given to her husband; her self-love betrays her, compatible with the narcissism of looking at her own face in the lake after her creation. Even Adam's sin is essentially evil; he prefers human love than God's service, just like Satan who preferred self-love than the Son of God's love. Thus, Adam's fall is inevitable, causing no Godly goodness in having proven infidel to God. In Aquinas's words,

Man is composed of a twofold nature, intellective and sensitive. Hence the devil, in tempting man, made use of a twofold incentive to sin: one on the part of the intellect, by promising the Divine likeness through the acquisition of knowledge which man naturally desires to have; the other on the part of sense. This he did by having recourse to those sensible things, which are most akin to man, partly by tempting the man through the woman who was akin to him in the same species; partly by tempting the woman through the serpent, who was akin to them in the same genus; partly by suggesting to them to eat of the forbidden fruit, which was akin to them in the proximate genus. (1981: II-II q.165 a.2)

However, the triple sin committed by Satan, Eve, and Adam serves God's Will, and $\mathrm{He}$ is the only one who can turn evil into goodness. The Son of God's voluntary sacrifice serves this fact, as it was directly ordained by Milton's God in Book III. In Draper's words, "God permits pain in order to advance morality." In fact, God wants that humankind freely and willfully performs right actions than wrong ones. He does not force humanity to merely perform "morally right actions", but 
He controls "the balance of right over wrong actions". God may use pain or evil to have human beings freely undertake right actions, and God knows beforehand that some human beings would perform right actions if they are given the chance (2001: 191). Hence the Son of God's voluntary decision to be sacrificed for humankind's bliss, a fact which God knew the Son would do. It is worth saying that suffering, Crucifixion, and death are essentially evil, but they are used to redeem humankind and establish God's Grace. It is really easy for God "to make good from the good", even "to make good out of nothing" (Adams 2001: 303). Lamenting the Fall, Milton has God prefer a human world without evil: "Happier had it sufficed him [Adam] to have known / Good by itself, and evil not at all" (PL, XI. 88-89). Augustine had also described the prelapsarian Adam in a condition where he had the potency to remain unfallen through the power of his will (1997a: 28). Even in that condition, Adam "had the grace in which, if he willed to remain, he would never have been evil and without which he could not have been good even with free choice". However, Augustine argues that through prelapsarian grace, humankind "had righteousness if he willed to," while grace after the Fall "is more powerful, for it makes one even to will and to will so strongly and to love with such ardor that by the will of the spirit one conquers the pleasure of the flesh which has contrary desires" (31).

Walker (2007) points out that God is not asking humankind to abandon reason and have faith in Him passively; rather, freedom means choosing either the authority of reason or that of the appetite. Milton's God makes the points that "I formed them free, and free they must remain, / Till they enthral themselves: I else must change / Their nature" ( $P L$, III. 124-126). The Fall, therefore, follows free choice, while humankind is created with the ability to choose correctly at the same time: "Against his will he can receive no harm / But God left free the Will, for what obeys / Reason, is free, and Reason he made right" (IX. 350-352). However, while Adam and Eve were deceived, Satan's disobedience was his own doing; therefore, they are granted forgiveness while "the other [Satan] none":

The first sort by their own suggestions fell,

Self-tempted, self-depraved: man falls deceived

By the other first: man therefore shall find grace,

The other none... (III. 129-132)

From another perspective, because Satan's free will led him to blasphemy, and because of his stubborn rejection of goodness and acceptance of evil, he eternalizes his own self-imposed misery. Thus, God decides to turn Satan's evil action in favor of humankind's bliss, since humankind was merely deceived, unlike Satan. Milton thus says,

... what can scape the Eye

Of God All-seeing, or deceave his Heart

Omniscient, who in all things wise and just, 
Hinder'd not Satan to attempt the minde

Of Man ... (X. 5-9)

God thus examines humankind's fidelity through Satan, and humankind is to achieve salvation through Satan's temptations, finally to witness the victory of God's Grace over the guilty consciousness and death.

Even "death" is promising after the Fall and earthly pains, although it is an end to humankind's bliss in Paradise. According to Aquinas, when we read that "God hath not made death" (Wis. 1:13), it is suggested that "God does not will death for its own sake." That is because "the order of justice" is part of "the order of the universe". This makes "penalty" necessary for sinners. Therefore, "God is the author of the evil which is penalty, but not of the evil which is fault" (1981: I q.49 a.2). In other words,

The evil of natural defect, or of punishment, He [God] does will, by willing the good to which such evils are attached. Thus in willing justice He wills punishment; and in willing the preservation of the natural order, He wills some things to be naturally corrupted. (I q.19 a.9)

Likewise, in Milton, God sentences mankind to death as a "penaltie of death, and suffering death," the penalty to his "transgression" which will befall his descendants too, "So onely can high Justice rest appaid" (PL, XII. 398-401). However, to make good out of evil, death is to free humankind from earthly sufferings for a reunion with God. Milton's God affirms this fact when he says,

... I at first with two fair gifts

Created him endowd, with Happiness

And Immortalitie: that fondly lost,

This other serv'd but to eternize woe;

Till I provided Death; so Death becomes

His final remedie, and after Life

Tri'd in sharp tribulation, and refin'd

By Faith and faithful works, to second Life,

Wak't in the renovation of the just,

Resignes him up with Heav'n and Earth renewd. (XI. 57-66)

Adam initially bemoans the thought of death and complains "Why is life giv'n / To be thus wrested from us? (XI. 502-503), and "Can thus / Th' Image of God in man created once / So goodly and erect, though faultie since, / To such unsightly sufferings be debas't / Under inhuman pains?" (XI. 507-511). Throughout the Fall, the "Makers Image" has forsaken Adam and Eve, as Michael tells Adam (XI. 515-516). Yet, it is death which can reunite humankind with that image. Moreover, when Adam sees that the death of the Son of God serves humankind's salvation, he humbly submits to God's Will (XI. 526). As a kind of death, the 
Son of God's sacrifice is to serve ultimate goodness. God holds that humankind "with his whole posteritie must dye, / Dye hee or Justice must; unless for him / Som other able, and as willing, pay / The rigid satisfaction, death for death." God asks for a heavenly volunteer to "be mortal to redeem human" and "just th' unjust to save" (III. 209-215). The Crucifixion, although evil, thus serves humankind's purgation from sin. Such sacrifice is in God's plan so that humankind be redeemed. The Son of God's death by his enemies is pure wickedness and tyranny against God, yet it serves divine goodness and humankind's salvation. Thus, Michael addresses Adam regarding the Son of God's suffering as such:

... thy punishment

He shall endure by coming in the Flesh

To a reproachful life and cursed death, Proclaiming Life to all who shall believe In his redemption, and that his obedience Imputed becomes theirs by Faith, his merits

To save them, not thir own, though legal works.

For this he shall live hated, be blasphem'd, Seis'd on by force, judg'd, and to death condemnd

A shameful and accurst, naild to the Cross

By his own Nation, slaine for bringing Life;

But to the Cross he nailes thy Enemies,

The Law that is against thee, and the sins

Of all mankinde, with him there crucifi'd (XII. 402-417)

Adam accordingly rejoices in the new chance of life and purgation due to the upcoming Crucifixion, so that:

O goodness infinite, goodness immense!

That all this good of evil shall produce,

And evil turn to good; more wonderful

Then that which by creation first brought forth

Light out of darkness! full of doubt I stand,

Whether I should repent me now of sin

By mee done and occasiond, or rejoyce

Much more, that much more good thereof shall spring,

To God more glory, more good will to Men

From God, and over wrauth grace shall abound. (XII. 469-478)

Producing "good of evil" and turning evil into good, as these lines suggest, express Milton's idea about the felix culpa, the "happy fault", "drawing upon parallels in Fletcher in England and Du Bratas in France, as well, perhaps, as Calvin (Inst. 3.23.7)" (Jeffrey 1992: 275). The Latin expression felix culpa derives from Augustine's writings about the Fall: "For God judged it better to bring good out 
of evil than not to permit any evil to exist" (1955: VIII. 27). Aquinas quoted this line to explain how the principle that "God allows evils to happen in order to bring a greater good therefrom" motivates the causal relationship between the Original Sin and the Son of God's Incarnation, stating that a higher realm is not avoided by sin (1981: III q.1 a.3), emphasizing Rom. 5.20: "Where sin abounded, grace did more abound." As a "paradoxical doctrine", the felix culpa deems that Adam's Fall is fortunate, "since without it human kind could not have experienced the unsurpassable joy of redemption" caused by "salvation through Calvary and the Atonement". Redemption as such is not the "restoration of prelapsarian innocence with no memory of sin or guilt", but the human sin compensated for (Jeffrey 1992: 274). Both concepts of the fall, the "happy fall" and the destructive fall, existed in Milton's time, and Milton chose to propagate the felix culpa as part of justifying God's ways to humankind, "by emphasizing the good that will emerge from the fall of Man" (Linn 2001: 81). The Fall seems not obligatory in Milton's view - in Book XI Milton has God prefer a human world without evil: "Happier had it sufficed him [Adam] to have known / Good by itself, and evil not at all" (PL, XI. 88-89), reflecting Augustine in The City of God: God had created Adam and Eve in a way "that if they discharged the obligation of obedience, an angelic immortality and a blessed eternity might ensue, without the intervention of death," and they "would have lived eternally with their bodies" (XIII. 1, 19). However, God has the power to create good out of evil. According to Lewalski, lines 469-478 of Book XII "do not affirm a simple concept of felix culpa", but rather they imply that "the Fall provided God an occasion to bring still greater good out of evil" based on His prelapsarian plan for the growth and perfection of humankind (Lewalski 2007: ft. 327). If the Fall had never happened, "the Incarnation and Redemption could never have occurred" (Lovejoy 1973: 164). Milton thus insistently tries to emphasize "the ultimate justness of a loving God's 'Eternal Providence"” (Sanders 1999: 332). Moreover, in Book II, addressing his fallen legion, Satan discusses God's manipulation of evil to create goodness: "A Universe of death, which God by curse / Created evil, for evil only good" (622-623).

By suggesting that God uses evil to create goodness, it is implied that either God possesses evil within Him or that He brings good out of evil, as we read in the Book of Genesis that He created light out of darkness and brought order out of chaos. But even the primary chaos is not evil for Milton:

For this original matter was not an evil thing, nor to be thought of as worthless: it was good, and it contained the seeds of all subsequent good. It was a substance, and could only have been derived from the source of all substance. It was in a confused and disordered state at first, but afterwards God made it ordered and beautiful. (1982: VI. 305-308)

Chaos is good because, in the Augustinian sense, anything that exists must include Divine goodness, and "chaos came forth from God ex deo in Milton's con- 
ception of creation", but lacking God's "active, creative goodness" (Schwartz 2009: 258). Order/chaos and good/evil suggest a "dynamic interplay of contraries" that God uses in favor of His Providence, and that Milton himself utilizes in developing his moral arguments (Steadman 1976: 274-275). Milton reflects this point as Book VI begins:

... There is a Cave

Within the Mount of God, fast by his Throne,

Where light and darkness in perpetual round

Lodge and dislodge by turns, which makes through Heav'n

Grateful vicissitude, like Day and Night;

Light issues forth, and at the other dore

Obsequious darkness enters, till her houre

To veile the Heav'n, though darkness there might well

Seem twilight here... (PL, VI. 4-12)

This signifies God's combination of good and evil, light and darkness, as archetypes initiating from the very beginning of the creation. In each binary pair, the parties serve each other. The relationship between good and evil, as general terms, thus seems symbiotic, further highlighting double-effect reasoning at work in Milton's argument. Likewise, Satan's rebellion and humankind's disobedience, though evil in nature, do happen by God's consent, since they are to serve God's Grace and human perfection. Adam is warned in Book III by Raphael of the evil threatening Paradise, a warning which implies a sort of pre-knowledge of evil on Adam's side, although he has Godly innocence. Raphael informs Adam of the Fall of the rebellious angels and of Satan's blasphemy. Adam then shows himself completely aware of the evil of temptation in his reaction to Eve's dream. What is achieved then is the "Knowledge of Good bought dear by knowing ill" (IV. 222), or the "knowledge of good lost, evil got" (XI. 87). These lines reflect Augustine when he proposes two kinds of knowing evil: by the knowledge of good and by experience (1972: 8.14.31). According to Poole, the prelapsarian Adam and Eve developed the former and the postlapsarian Adam and Eve experienced the latter. In the City of God, the prelapsarian mind of humankind is "a more static and a more implicitly frail original," with fewer experiences and freedom allowed. While Augustine emphasizes humankind's tranquility before the Fall - evil being known innocently by merely meditating over and avoiding the perversion of good - he also pities humankind as "more distant and unratiocinative", that is, innocent due to the "lack of perturbation" than through knowledge of abstaining from evil (Poole 2005: 26). The knowledge of good and the knowledge of evil, therefore, have a symbiotic relationship with each other, and the postlapsarian humankind can distinguish good better by knowing evil. Humankind is assured, in Adam's words, that God is "Mercifull over all his works, with good / Still overcoming evil" (PL, XII. 565-566), "that suffering for Truths sake / Is fortitude to highest victorie, / And to the faithful Death the Gate of Life" (XII. 569-571). And God's 
mercy seems to be the most important thing accompanying His justice. Adam here in fact reemphasizes God's statement of mercy in Book III, despite human sin:

\author{
... Man falls deceiv'd \\ By the other first: Man therefore shall find grace, \\ The other [Satan] none: in Mercy and Justice both, \\ Through Heav'n and Earth, so shall my glorie excel, \\ But Mercy first and last shall brightest shine. (III. 130-134)
}

In general terms, Milton's Arminianism in absolving God and His "permissive will" (III. 685) from the responsibility of the Fall reveals itself in different parts of the poem (III. 120-125; V. 527-528; X. 8-9; X. 44-46). As such, the "providential cosmos of Paradise Lost, with its emphasis on God's sovereignty, discounts any notion of a capricious Fortune, Fate or Chance" (Loewenstein 2004: 74). Moreover, emphasizing that "Man shall find grace" after the Fall (PL, III. 131), God further underlines Milton's Arminian theology, setting the poem "apart from the more orthodox Calvinist determinism of Milton's age" (Loewenstein 2004: 75). But the paradox lies in Milton's Calvinistic portrayal of a sitting God in Heaven watching Satan creeping into Paradise to deceive Eve, letting the Fall happen. By not preventing Satan from tempting Eve, God does not will the Fall but merely lets it happen. Is God thus unable to stop Satan or evil? Is He unable to read His creatures' minds? A positive answer to these questions deems God impotent in managing His world, harshly questioning His ultimate Goodness. Therefore, every event in the universe, if meant to be purposeful in essence, shall be linked to God's Will and Goodness. What is the meaning of the Fall if it should not be a happy fault? Is God's best creature a total failure then? God lets the Fall happen according to its creatures' consciousness over what they do, i. e., their will. The Fall for humankind is thus, in Milton's words, "the triall of virtue, and the exercise of truth" (1982: II. 527-528). This trial must be visited by "a virtue that though confronted by the beauty and the pleasures of a world of sense and having the power to wander beyond all limit and satiety," still chooses goodness and not evil. Obedience is then not at all "blind" but "a matter of choice" (Greenlaw 1917: 200). Not letting any evil happen necessitates humankind's absolute submission to God, a passive life like that of non-human creatures, except the fallen angles and obedient Angels, which act by instinct than consciousness. Even when God decrees that "man shall find grace", it is God's will to do so, based on his foreknowledge. Milton's paradox thus dynamically fluctuates between Calvinism and Arminianism; in Poole's words, "Milton's understanding of the Fall and of [the] original sin clearly follows broadly Calvinist lines, with Arminian qualifications (2005: 145). As Milton observes in the Christian Doctrine, "God made his decrees conditional... for the very purpose of allowing free causes to put into effect the freedom which he himself gave them" (1982: VI. 160), including, as God remarks in Paradise Lost, the freedom to err (III. 99). Just as choosing not to choose is still a choice, allowing humanity to have the freedom even to err is 
still an act decreed by God. What remains in vindicating God from evil is His inherent goodness, a fact which shall be used to make sense of the present evil in His universe. The Fall is then the foreseen-but-not-intended evil side effect when God is to bestow His Mercy on humanity, so that "Man should find grace, For which both Heav'n and Earth shall high extol Thy praises," as the Son of God addresses God (III. 145-147). This act of mercy stabilizes God's "goodness" and "greatness" (III. 165), as his "Eternal purpose hath decreed" (III. 172). Even, the Son of God himself acts as "the embodiment of mercy, divine love, and voluntary obedience" (Loewenstein 2004: 75), issues which could not develop without the Fall. God does indeed assure the Son that humankind will be saved, thanks to heavenly grace "Freely voutsaft" ( $P L$, III. 175).

Milton makes the end of Paradise Lost optimistic. Adam and Eve are no longer the Godly innocents before the Fall. As they leave Paradise, their innocence has matured into experience, and now they observe the world with higher knowledge. Thus Michael concludes his words with Adam as such:

That ye may live, which will be many dayes,

Both in one Faith unanimous though sad,

With cause for evils past, yet much more cheer'd

With meditation on the happie end. (XII. 602-605)

Michael assures Adam that still more goodness is to follow and that the Fall is not altogether doomed. Paradise Lost thus "defines virtue in the context of evil" and "shows the need for truth and falsehood to grapple" (Loewenstein 2004: 105). Had Adam and Eve remained in Paradise without disobedience, they would have given birth to children who would remain in "original righteousness and in sanctifying grace, but not confirmed in righteousness" (Duncan 1972: 73). Such double-effect reasoning in justifying God's ways to humankind, in Milton's words, thus may help us in making sense of the paradoxes in human Fall and Salvation. As Augustine says, "man would have had no prospect of any special praise, if he were able to lead a good life simply because there was none to persuade him to lead an evil life" (1972: XI. 4), because

In this universe, even what is called evil, when it is rightly ordered and kept in its place, commends the good more eminently, since good things yield greater pleasure and praise when compared to the bad things. For the Omnipotent God, whom even the heathen acknowledge as the Supreme Power over all, would not allow any evil in his works, unless in his omnipotence and goodness, as the Supreme Good, he is able to bring forth good out of evil. (1955: III. 11)

God does not intend humankind's suffering and death; He does not will them as ends. They are only means to an end, which is the establishment of God's Grace, a fact not possible during the happily-ever-after life of Adam and Eve in Paradise. 


\section{Conclusion}

Applying the principle of double-effect reasoning to Milton's justification in Paradise Lost is in accordance with his version of the felix culpa. As such, Milton's argument seems to draw from Augustine and Aquinas - whose views altogether are not different from Milton's in kind but in degree. That God creates goodness out of evil does not necessitate the coexistence of evil and goodness from the very beginning of the world. Rather, evil is inherent where goodness is perverted, and goodness derives from God, so that self-interest equals betraying God and His goodness. The "happy fall" was based on God's own prelapsarian divine Providence, so that perfection towards the Godhead becomes possible through the knowledge of what was not going to be created, the knowledge of evil. God could but did not prohibit Satan from his rebellion, both to let his free will choose for him, in an Arminian sense, and to let humankind's Fall happen, in a Calvinist sense. The Fall was also to prove the Son of God's devotion to the Will of God, through Crucifixion, in order to redeem human beings. Accordingly, to manifest His Will in the world, Milton's God appears to let evil accompany goodness, not as intended for the sake of evil but as the inevitable side effect of the propagation of the good Will of God. In applying the three general principles of double-effect reasoning to Milton's argument, three main points are thus worth considering. 1) The Fall was not evil per se regarding the notion of the felix culpa, independent of its evil effects for humanity; Adam and Eve could not possess true virtue by ultimate obedience and prelpsarian innocence. Accordingly, the foreseen-but-not-intended evil Fall causes humankind's final goodness in acquiring higher knowledge in accordance with the God-given reason. Even death shall be redeeming to relieve humankind from earthly pain, despite the fact that it was decreed by God to end human eternal life in Paradise. 2) God intended the good and not the evil, since He had given humankind free will and reason to choose wisely. He had also bestowed free will on Satan and other angels not to passively obey Him. And, 3) God had grave reasons for His plans and actions, based on His Divine Will and Providence, in taking into consideration the necessity of evil and bringing goodness out of it. Altogether, justifying God's ways to humanity, either in the form of accusing God or acquitting Him, presupposes God's inherent Will in creating good out of evil, since one term without the other lacks true significance and necessitates either passive obedience to God or Satanic disobedience away from God's Will, respectively.

\section{Notes}

Lines from Paradise Lost are from Barbabara K. Lewalski's edition (2007) of 12 Books. Regarding the citation of lines from the poem henceforward, the number of Books and lines are given after $P L$.

2 In the references from the Summa thelogica, II-II q.64 a.7, for example, 'II-II' refers to the second part of the second part of the Summa, 'q.' refers to the question, 'a.' to the article. Where the reference is ' $\mathrm{I}-\mathrm{II}$ ', it thus means the first part of the second part. 
The citing here stands for Augustine's Confessions, Book III, Chapter 7.

These lines are Poole's translation, adapted from Complete Prose Works of Milton, Vol. I, p. 363. This specific comment dated 1639-40, according to Poole (2005: 225).

\section{References}

Adams, Marilyn McCord (2001) 'The problem of the hell: a problem of evil for Christians'. In: Rowe, William L. (ed.) God and the Problem of Evil. Oxford: Blackwell Publishing Ltd, 282309.

Aquinas, Thomas (1981) Summa theologiae. Trans. Fathers of the English Dominican Provinc. Notre Dame: Christian Classics.

Augustine of Hippo (2009) Confessions. Trans. Henry Chadwick. Oxford: Oxford University Press.

Augustine of Hippo (1955) Confessions and Enchiridion. Ed. \& Trans. Alber Cook Outler. Louisville, The Westminster Press.

Augustine of Hippo (1957-1972) De civitate Dei [City of God], 7 Vols. Ed. \& Trans. G. E. McCracken et al. London: Heinemann.

Augustine of Hippo (1972) De Genesi ad litteram [Literal Commentary on Genesis], 2 Vols. In La Genèse au sens littéral. Trans. P. Agaësse and A. Solignac. Paris: Desclée de Brouwer.

Augustine of Hippo (2010) On the Free Choice of the Will, On Grace and Free Choice, and Other Writings. Ed. \& Trans. Peter King. Cambridge: Cambridge University Press.

Augustine of Hippo (1997a) Rebuke and Grace. In Answer to the Pelagians, IV. Ed. John E. Rotelle. Trans. Roland J. Teske. New York: New City Press, 109-148.

Augustine of Hippo (1997b) The Punishment and Forgiveness of Sins and the Baptism of Little Ones. In Answer to the Pelagians, I. Ed. John E. Rotelle. Trans. Roland J. Teske. New York: New City Press, 19-132.

Augustine of Hippo (1997c) The Spirit and the Letter. In Answer to the Pelagians I. Ed. John E. Rotelle. Trans. Roland J. Teske. New York: New City Press, 133-194.

Baxter, Richard (1649) Aphorismes of Justification: with their explication annexed: wherein also is opened the nature of the covenants, satisfaction, righteousnesse, faith, works, \& c.: published esspecially for the use of the church of Kederminster in Worcestershire by their unworthy teacher, Ri. Baxter. London: Printed for Francis Tyton.

Boethius (1609) Five Bookes of Philosophicall Comfort. London: Mathew Lownes.

Bryson, Michael (May 2002) "“That far be from thee": Divine evil and justification in Paradise Lost'. Milton Quarterly 36 (2), 87-105.

Campbell, W. Gardner (2014) 'Temptation'. In: Schwartz, Louis (ed.) The Cambridge Companion to Paradise Lost. New York: Cambridge University Press, 164-178.

Cavanaugh, Thomas (2006) Double-Effect Reasoning: Doing Good and Avoiding Evil. Oxford: Oxford University Press.

Colebrook, Clair (2008) Milton, Evil, and Literary History. London: Continuum.

Danielson, Dennis (1999) 'The fall and Milton's theodicy'. In: Danielson, Dennis (ed.) The Cambridge Companion to Milton. $2^{\text {nd }}$ ed. Cambridge: Cambridge University Press, 144-159.

Draper, Paul (2001) 'Pain and pleasure: an evidential problem for theists'. In: Rowe, William L. (ed.) God and the Problem of Evil. Oxford: Blackwell Publishing Ltd, 180-202.

Duncan, Joseph Ellis (1972) Milton's Earthly Paradise: A Historical Study of Eden. Minneapolis: University of Minnesota Press.

Greenlaw, Edwin (Apr. 1917) 'A Better Teacher than Aquinas'. Studies in Philology 14(2), 196-217.

Innes-Parker, Catherine (2011) 'Critical essay on Paradise Lost'. In: Constantakis, Sara (ed.) Epics for Students. $2^{\text {nd }}$ ed. Farmington Hills, MI: Cengage Gale, 595-598.

Jeffrey, David L. (1992) A Dictionary of Biblical Tradition in English Literature. Grand Rapids: Wm. B. Eerdmans Publishing. 
Lawrence, Karen, Betsy Seifter, and Lois Ratner (1985) The McGraw-Hill Guide to English Literature: Volume One, Beowulf to Jane Austen. New York: McGraw-Hill, Inc.

Lewis, Clive Staples (1969) A Preface to Paradise Lost. Oxford: Oxford University Press.

Linn, Bob (2001) CliffsNotes: Milton's Paradise Lost. New York: IDG Books Worldwide, Inc.

Loewenstein, David (2004) Milton: Paradise Lost. $2^{\text {nd }}$ ed. Cambridge: Cambridge University Press. Lovejoy, Arthur Oncken (1973) 'Milton and the paradox of the fortunate fall'. ELH 4, 161-179.

Mautner, Thomas (2005) The Penguin Dictionary of Philosophy. $2^{\text {nd }}$ ed. London: Penguin Books.

McFarland, Ian A. (2010) In Adam's Fall: A Meditation on the Christian Doctrine of Original Sin. Malden: Wiley-Blackwell.

McIntyre, Alison (2011) 'Doctrine of Double Effect'. In: Zalta, Edward N. (ed.) The Stanford Encyclopedia of Philosophy. http://plato.stanford.edu/archives/fall2011/entries/double-effect - "Accessed on 15 June 2015"

Milton, John (1982) Complete Prose Works of John Milton, 8 Vols. Ed. D. Wolfe et al. New Haven: Yale University Press.

Milton, John (1957) John Milton: Complete Poems and Major Prose. Ed. Merritt Hughes. New York: Odyssey Press.

Milton, John (2007) Paradise Lost. Ed. Barbabara K. Lewalski. Oxford: Blackwell Publishing.

Nagel, Thomas (1980) 'The limits of objectivity'. In: McMurrin, Sterling (ed.) The Tanner Lectures on Human Values. Salt Lake City: University of Utah Press, 77-139.

Plontingo, Alvin (2002) God, Freedom, and Evil. Grand Rapids, William B. Eerdmans Publishing Company.

Poole, William (2005) Milton and the Idea of the Fall. Cambridge: Cambridge University Press.

Sanders, Andrew (1999) The Short Oxford History of English Literature. $2^{\text {nd }}$ ed. London: Oxford University Press.

Schwartz, Louise (2009) Milton and Maternal Mortality. Cambridge: Cambridge University Press.

Steadman, John (August 1976) 'The idea of Satan as the hero of Paradise Lost'. Symposium on John Milton: Proceedings of the American Philosophical Society 120 (4), 253-294.

The Bible: Authorized King James Version with Apocrypha (1998) Oxford: Oxford University Press.

Walker, William (2007) 'On reason, faith, and freedom in Paradise Lost'. Studies in English Literature 1500-1900 47 (1), 143-159.

Jafar Mirzaee Porkoli is an Assistant Professor in English Literature at Razi University, Iran. $\mathrm{He}$ received his $\mathrm{PhD}$ in English Literature from Victoria University of Wellington, New Zealand, in 2013. He conducts researches in Renaissance literature, literary theory, deconstruction, narrative studies, and comparative literature.

Address: Jafar Mirzaee Porkoli, Assistant Professor, Department of English, Faculty of Humanities, Razi University, Kermanshah, Iran. [email: jmirzaeep@gmail.com]

MOHAMmAD-JaVAD HAJ'JARI is a PhD Candidate in English Literature at Razi University, Iran. He is also a Lecturer in English at SPNU in Shiraz, Iran. His field of research includes literary theory and criticism, interdisciplinary studies, literature and philosophy, and postmodernism.

Address: Mohammad-Javad Haj'jari, Department of English, Faculty of Humanities, Razi University, Kermanshah, Iran. [email: aminhajjari@gmail.com] 